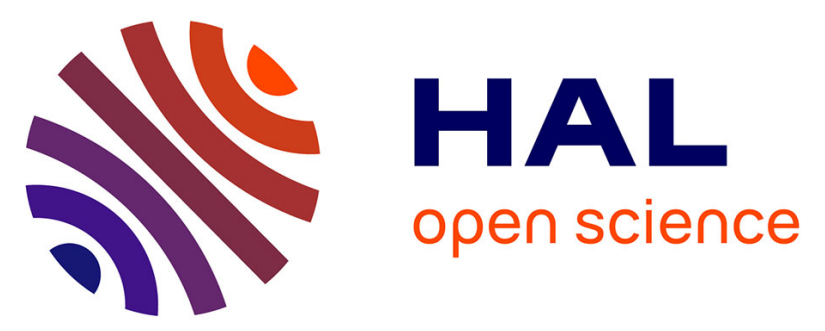

\title{
Copper Content and Export in European Vineyard Soils Influenced by Climate and Soil Properties
}

Boris Droz, Sylvain Payraudeau, José Antonio Rodríguez Martín, Gergely

Tóth, Panos Panagos, Luca Montanarella, Pasquale Borrelli, Gwenael Imfeld, José Antonio, Rodríguez Martín

\section{To cite this version:}

Boris Droz, Sylvain Payraudeau, José Antonio Rodríguez Martín, Gergely Tóth, Panos Panagos, et al.. Copper Content and Export in European Vineyard Soils Influenced by Climate and Soil Properties. Environmental Science and Technology, 2021, 55 (11), pp.7327-7334. 10.1021/acs.est.0c02093 . hal03378939

\section{HAL Id: hal-03378939 \\ https://hal.science/hal-03378939}

Submitted on 18 Oct 2021

HAL is a multi-disciplinary open access archive for the deposit and dissemination of scientific research documents, whether they are published or not. The documents may come from teaching and research institutions in France or abroad, or from public or private research centers.
L'archive ouverte pluridisciplinaire HAL, est destinée au dépôt et à la diffusion de documents scientifiques de niveau recherche, publiés ou non, émanant des établissements d'enseignement et de recherche français ou étrangers, des laboratoires publics ou privés. 
1 Copper Content and Export in European Vineyards

3

4 Sustainability, Via E. Fermi 2749,21027 Ispra, Italy
${ }^{\square}$ Department of Earth and Environmental Sciences, University of Pavia, Via Ferrata, 1,

‡ Department of the Environment, Instituto Nacional de Investigación y Tecnología Agraria y Alimentaría (INIA), Carretera de la Corunã 7.5, 28040 Madrid, Spain

$\S$ Institute of Advanced Studies, Chernek str. 14., 9730 Köszeg, Hungary
"European Commission, Joint Research Centre (JRC), Institute for Environment and

$\S$ Institute of Advanced Studies, Chernek str. 14., 9730 Köszeg, Hungary
"European Commission, Joint Research Centre (JRC), Institute for Environment and Sustainability, Via E. Fermi 2749, 21027 Ispra, Italy
tment of Earth and Environmental Sciences, University of Pavia, Via Ferrata, 1,

Boris Droz, ${ }^{\dagger^{*}}$ Sylvain Payraudeau, ${ }^{\dagger}$ José Antonio Rodríguez Martín, ${ }^{\ddagger}$ Gergely Tóth, ${ }^{\S}$ Panos Panagos," Luca Montanarella," Pasquale Borrelli ${ }^{\square, *}$ \& Gwenaël Imfeld †* $^{*}$

${ }^{\dagger}$ Institut Terre et Environnement de Strasbourg, Université de Strasbourg, ENGEES, CNRS, UMR 7063, 5 rue Descartes, Strasbourg F-67084, France 1

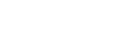
27100 Pavia, Italy

$14 \quad ¥$ Department of Biological Environment, Kangwon National University, Chuncheon 15 24341, Republic of Korea 
18 Copper-based fungicides $\left(\mathrm{Cu}_{\mathrm{f}}\right)$ are used in European $(\mathrm{EU})$ vineyards to prevent fungal

19 diseases. Soil physicochemical properties govern locally the variation of total copper

20 content $\left(\mathrm{Cu}_{t}\right)$ in $\mathrm{EU}$ vineyards. However, variables controlling $\mathrm{Cu}_{t}$ distribution at larger

21 scale are poorly known. Here machine learning techniques were used to identify

22 governing variables and to predict the $\mathrm{Cu}_{t}$ distribution in EU vineyards. Precipitation,

23 aridity and soil organic carbon are key variables explaining together $45 \%$ of $\mathrm{Cu}_{\mathrm{t}}$

24 distribution across EU vineyards. This underlines the effect of both climate and soil

25 properties on $\mathrm{Cu}_{\mathrm{t}}$ distribution. The average net export of $\mathrm{Cu}$ at the EU scale is $0.29 \mathrm{~kg}$

$26 \mathrm{Cu} \mathrm{ha}{ }^{-1}$ which is two orders of magnitude less than the net accumulation of $\mathrm{Cu}(24.8 \mathrm{~kg}$

$27 \mathrm{Cu} \mathrm{ha}{ }^{-1}$ ). Four scenarios of $\mathrm{Cu}_{\mathrm{f}}$ application were compared. The current EU regulation

28 with a maximum of $4 \mathrm{~kg} \mathrm{Cu} \mathrm{ha}^{-1}$ year $^{-1}$ may increase by $2 \%$ the EU vineyard area

29 exceeding the predicted no-effect concentration (PNEC) in soil in the next 100 years.

30 Overall, our results highlight vineyard areas requiring specific remediation measures

31 and strategies of $\mathrm{Cu}_{\mathrm{f}}$ use to manage a trade-off between pest control and soil and water

32 contamination. 


\section{INTRODUCTION}

34 Copper-based fungicides $\left(\mathrm{Cu}_{\mathrm{f}}\right)$ are intensively used in European vineyards since the

35 end of the $19^{\text {th }}$ century to prevent fungal disease such as 'Downy Mildew'. ${ }^{1} \mathrm{Cu}_{\mathrm{f}}$

36 application doses and timing vary across regions depending on practices, regulation,

37 hydro-climatic conditions and vine variety. The European Union (EU 2018/1981)

38 regulation recently decreased from 6 to $4 \mathrm{~kg} \mathrm{Cu} \mathrm{ha}^{-1}$ year $^{-1}$ the maximal dose allowed. ${ }^{2}$

39 However, doses as high as $50 \mathrm{~kg} \mathrm{Cu} \mathrm{ha}^{-1}$ year $^{-1}$ were applied frequently for decades in

40 the mid- $20^{\text {th }}$ century. $^{3}$ Today, the total copper content in topsoil $\left(\mathrm{Cu}_{\mathrm{t}}\right)$ exceeds $100 \mathrm{mg}$

$41 \mathrm{Cu} \mathrm{kg}{ }^{-1}$ in $15 \%$ of the European vineyard area. This corresponds to the average

42 proposed threshold values for which soil remediation is needed. ${ }^{4-6}$ European vineyards

43 represent more than $50 \%$ of the total vineyard surface worldwide. ${ }^{7}$ Although vine

44 growing accounts for only $3.3 \%$ of the agricultural area in Europe, it uses $86 \%$ of total

45 fungicides consumed in Europe. ${ }^{8}$ Hence, vineyard soil is often more contaminated by

$46 \mathrm{Cu}_{\mathrm{f}}$ than soils of any other agricultural soils. $\mathrm{Cu}_{\mathrm{f}}$ accumulates in soil and can impact soil

47 organisms and plants, ${ }^{9}$ thereby reducing soil fertility ${ }^{10}$ and productivity. ${ }^{11}$ In contrast,

48 leaching ${ }^{12}$ and surface runoff ${ }^{13,14}$ export $\mathrm{Cu}_{\mathrm{f}}$ from vineyard soil, which can contaminate

49 aquatic ecosystems ${ }^{15}$ and drinking water resources. ${ }^{16}$

$50 \quad \mathrm{Cu}_{\mathrm{f}}$ mobility in topsoil controls $\mathrm{Cu}_{t}$ accumulation and off-site export. Cu mobility in soil

51 is mainly controlled by (i) sorption on organic matter, ${ }^{17}$ and to a lesser extent on clay

52 and Fe-, Mn-(hydr)oxide and carbonate, ${ }^{18}$ (ii) $\mathrm{pH}$-redox dependency since alkaline soil

53 increase the proportion of available binding sites on organic matter. ${ }^{17,19} \mathrm{Cu}$ sorbed on

54 fine particle matter may result in $\mathrm{Cu}$ export in runoff. ${ }^{13,14}$ Hydro-climatic and field

55 conditions indirectly control $\mathrm{Cu}$ export by (i) affecting soil properties, ${ }^{20}$ (ii) mediating 
56 dissolved and particulate $\mathrm{Cu}_{\mathrm{f}}$ transport, and (iii) modifying preferential transport. ${ }^{21}$

57 Accordingly, presumed or established processes governing $\mathrm{Cu}_{\mathrm{t}}$ mobility in vineyard soil

58 may co-occur and/or may be interrelated (Table 1). Variables governing $\mathrm{Cu}_{t}$ and 59 dynamics in vineyard soil are, however, examined in laboratory and field studies

60 separately. As a result, the understanding of variables governing $\mathrm{Cu}_{t}$ in soil remains

61 study- or site-specific. The identification of variables governing $\mathrm{Cu}_{t}$ in vineyard soil and

62 leading to $\mathrm{Cu}$ accumulation and/or off-site export over time is necessary to evaluate the

63 current and future distribution of $\mathrm{Cu}_{\mathrm{t}}$ at the European scale.

64 In this context, a major issue is to predict the spatial variation of $\mathrm{Cu}_{t}$ in the European

65 vineyards, to quantify $\mathrm{Cu}$ accumulation and export and to identify priority areas requiring

66 soil remediation. The purpose of this study was (i) to identify key variables potentially

67 governing $\mathrm{Cu}_{t}$ in vineyard topsoil $(0-30 \mathrm{~cm})$, (ii) to predict average $\mathrm{Cu}_{t}$ at European

68 vineyards scale using machine learning technics, and (iii) to estimate $\mathrm{Cu}_{\mathrm{t}}$ accumulation,

69 export and associated toxicity for terrestrial trophic levels, for historical, current and

70 future scenarios of $\mathrm{Cu}_{\mathrm{f}}$ application (i.e, 0, 2, 4 or $8 \mathrm{~kg} \mathrm{Cu} \mathrm{ha}^{-1} \mathrm{y}^{-1}$ ).

72 MATERIALS AND METHODS

73 Topsoil total Copper Datasets.

$74 \mathrm{Cu}_{\mathrm{t}}$ datasets $\left(\mathrm{Cu}_{\mathrm{t}}\right.$, dat; i.e., soils within $\left.0-30 \mathrm{~cm}\right)$ were obtained from several soil 75 surveys across European vineyards $\left(-9.4^{\circ}\right.$ to $42^{\circ} \mathrm{E} ; 35^{\circ}$ to $53^{\circ} \mathrm{N}$; SI, Figure S1) 76 delineated by the Corine Land Cover (CLC 2012; v18.5.1; http://land.copernicus.eu). In

77 total, 1,202 $\mathrm{Cu}_{\mathrm{t} \text {, dat }}$ measurements (average: $27.8 \mathrm{mg} \mathrm{Cu} \mathrm{kg}^{-1}$; min-max: $0.54-774 \mathrm{mg}$ $78 \mathrm{Cu} \mathrm{kg}^{-1}$ ) were sampled between 1992 and 2016 (median = 2008, standard deviation 
$79(\mathrm{SD})=5)$ and used in our study. Summary of the studied $\mathrm{Cu}_{\mathrm{t}}$, dat are provided in Table

$80 \mathrm{~S} 1$ of the Supporting Information (SI). Although the $\mathrm{Cu}$ quantification methods differ

81 among datasets, inter-comparability between datasets has been demonstrated

82 previously for the methods used in our study. ${ }^{22}$ The impact of topsoil sampling depth

83 (first 20 or $30 \mathrm{~cm}$ ) and sampling time span on the average prediction of $\mathrm{Cu}_{t}\left(\mathrm{Cu}_{\text {pred }}\right)$ at

84 the European scale remains low (SI, section Influence of heterogeneous sampling

85 depths and time on the Cu prediction). The heterogeneity of topsoil sampling depth and

86 time span did not significantly (within $2 \sigma$ ) impact the average predictions of $\mathrm{Cu}_{t}$ at the

87 European scale.

$89 \quad$ Predictive Variables.

90 Soil properties, topology, climate and land cover were selected and evaluated as

91 hypothetic predictive variables of $\mathrm{Cu}_{t}$ (Table $1 \&$ SI, Table S2). Geogenic, i.e., from bed

92 rocks, ${ }^{23}$ and atmospheric non-agricultural anthropogenic inputs of $\mathrm{Cu}$, i.e., mining,

93 smelter, sewage sludge and vehicle brake pads are sources of $\mathrm{Cu}$ contributing from 5 to

$94100 \mathrm{~g} \mathrm{Cu} \mathrm{ha}^{-1}$ year $^{-1}$ whereas about $8 \mathrm{~kg} \mathrm{Cu} \mathrm{ha}^{-1}$ years ${ }^{-1}$ of $\mathrm{Cu}_{\mathrm{f}}$ are applied on

95 vineyards. ${ }^{24}$ Topsoils surrounding Cu mining or smelter, that may reach up to $6 \mathrm{~g} \mathrm{Cu} \mathrm{kg}^{-}$

$96{ }^{1,25,26}$ were not identified close to vineyard areas. Consequently, geogenic and industrial

97 sources of Cu were not considered in this study.

98

99

100

101 
102 Table 1. Hypothetic Predictive Variables Governing the Total Copper Content in

103 Vineyard Topsoil $\left(\mathrm{Cu}_{\mathrm{t}}\right)$ Leading to $\mathrm{Cu}_{\mathrm{t}}$ Accumulation and/or off-site Export.

\begin{tabular}{|c|c|}
\hline Variables $^{a}$ & Processes \\
\hline \multicolumn{2}{|l|}{ Soil properties } \\
\hline $\begin{array}{l}\text { Soil } \\
\text { physicochemical } \\
\text { properties affect } \\
\text { Cut mobility }\end{array}$ & $\begin{array}{l}\mathrm{Cu}_{\mathrm{t}} \text { correlates positively to soil organic matter since } \mathrm{Cu} \\
\text { preferentially sorbs to organic matter in soil, }{ }^{13,17} \text { which } \\
\text { affects } \mathrm{Cu}_{\mathrm{t}} \text { mobility. Higher } \mathrm{pH} \text { increases sorption sites } \\
\text { (e.g. negative charge) for } \mathrm{Cu} \mathrm{u}_{\mathrm{t}} \text { on clay, organic matter and } \\
\text { sand containing carbonate, }{ }^{19} \text { and reduces } \mathrm{Cu}_{\mathrm{t}} \text { leaching. }{ }^{12}\end{array}$ \\
\hline $\begin{array}{l}\text { Soil moisture } \\
\text { influences soil } \\
\text { biogeochemistry }\end{array}$ & $\begin{array}{l}\text { Soil moisture directly affects microbial respiration and } \\
\text { activities in soil resulting in biogeochemical } \\
\text { gradients. }{ }^{27,28} \mathrm{Cu} \text { occurs as } \mathrm{Cu}(\mathrm{II}) \text { in oxic soils. In } \\
\text { contrast, } \mathrm{Cu}(\mathrm{II}) \text { may potentially precipitate to less mobile } \\
\mathrm{Cu}(\mathrm{I}) \text { forms in anoxic soils. }{ }^{17,29}\end{array}$ \\
\hline
\end{tabular}

Topography/climate

Topography and climate conditions drive soil erosion

Hydro-climatic conditions influence $\mathrm{Cu}$ application doses

Hydro-climatic conditions influence (i) soil chemistry

(ii) Vegetation growth
Greater rainfall depth and higher slope length enhance soil erosion by runoff. ${ }^{21} \mathrm{Cu}_{t}$ is mostly bound to suspended particles matter (SPM) in topsoil $\left(\sim 85 \%{ }^{13,14}\right)$ where SPM-bound $\mathrm{Cu}$ can account for $84.4 \%$ of the total $\mathrm{Cu}_{\mathrm{t}}$ exported by runoff. ${ }^{14}$

Intense rainfalls during warm conditions favor the development of 'Downy Mildew'. This increases the frequency and amount of $\mathrm{Cu}_{t}$ use in some areas to control it. ${ }^{30,31}$

Arid environments (with higher Al values), characterized by higher soil $\mathrm{pH}$ and oxidizing soils, ${ }^{20}$ favor $\mathrm{Cu}_{\mathrm{t}}$ accumulation (see soil physicochemical properties above). In contrast, arid soils tend to lose more soil organic matter and associated $\mathrm{Cu}_{t}$ since $\mathrm{Cu}$ is preferentially associated to soil organic matter. ${ }^{13,17}$

Optimal conditions for vegetation growth depend on temperature, soil moisture and solar radiation, and vary across plant growth stages. ${ }^{32}$ Vegetation growth controls $\mathrm{Cu}_{\mathrm{t}}$ mobility indirectly by limiting erosion via surface runoff and thus can be related to $\mathrm{Cu}_{t}$. 
$\begin{array}{ll}\text { (iii) Plant uptake } & \text { Cu uptake from soil by plants remains limited: } 0.1-7.2 \% \\ \text { by } \text { wild }^{33} \text { and } 0.1-3.8 \% \text { by the vineyard } & \text { plants of the }\end{array}$ $\mathrm{Cu}_{\mathrm{t}}$. Hence, plants only marginally decrease $\mathrm{Cu}_{\mathrm{t}}$ in soil.

Plant cover

Plant cover affects surface runoff and organic matter content in topsoil
Plant cover, i.e., vine and grass in vineyards, can stabilize the vineyard soil and thus limit erosion via surface runoff. ${ }^{35}$ In addition, plant decomposition can slightly increase organic matter content in topsoil, ${ }^{36}$ thereby reducing Cu mobility.
104

105

106

107

114 t-test; $p$-value average $>0.01$ ) and did not display any spatial correlation (Moran's test; $115 \mathrm{I}_{\text {average }}=-0.211 \pm 0.09 ; p$-value $\left.>0.01\right)$. The selection of variables was carried out from 116 the 24 original predictive variables (SI, Table S2) to limit collinearity between predictive 117 variables and optimize model predictions as described elsewhere: ${ }^{37}$ (i) Pearson 118 correlation was used to discard variables providing the similar information and (ii) 119 principal component analysis (PCA) was used to discard noise variables containing the 120 least information. ${ }^{38}$ 20 least information. ${ }^{38}$

${ }^{a}$ Hypothetic predictive variables governing $\mathrm{Cu}_{\mathrm{t}}$ in vineyard soil. Variables associated with each process are provided in the SI, Table S2. Processes were identified based on experimental studies in vineyard or related soil.

Predictive variables were computed or directly obtained on a grid cell of $250 \times 250 \mathrm{~m}$ for the study area. Details concerning building spatial variables are provided in the in SI, Table S2 \& S3. $\mathrm{Cu}_{\mathrm{t}}$, dat coordinates were used to extract values of each predictive variable in the corresponding grid cells. Extracted data were then used to select variables and calibrate the model (details in SI). Extracted data represented adequately the range of predictive variables within the prediction domain (details given in SI; paired 
123 Prediction of Total Copper Content in European Vineyard Topsoil.

124 The variable selection procedure highlight that the following variables were predictive 125 of the average $\mathrm{Cu}_{\mathrm{t}}$ in European vineyards: clay and silt fractions (\%), soil organic carbon 126 content $\left(\mathrm{C}_{\text {org }}\right.$ \% \%), soil $\mathrm{pH}$ (unitless), aridity index ( $\mathrm{Al}$; unitless), annual average

127 temperature $\left(\mathrm{T}_{\mathrm{av}} ;{ }^{\circ} \mathrm{C}\right)$, annual rainfall (rainfall; $\mathrm{mm}$ ), soil moisture content (moisture; \%),

128 the enhanced vegetation index (EVI; unitless) and slope (degree; SI, Table S3). This

129 selection is consistent with predictive variables reported previously (Table 1). Three

130 independent machine learning techniques, i.e., neural networks ( $R$ package nnet $v$ 7.3-

131 12), random forest ( $R$ package randomForest v.4.6-12) and bagging tree ( $R$ package

132 ipred v.0.9-5), were used in parallel and were averaged into an ensemble model (ENS;

133 details in SI) for the final prediction, as described elsewhere. ${ }^{39}$ The ENS resulted in

134 fewer false predictions and higher predictive accuracy than a single model. Consistency

135 of $\mathrm{Cu}_{\text {pred }}$ was evaluated for each grid cell on a SD of 1,000 predictions for each machine

136 learning technique. Model performance was evaluated using a 10-fold cross-validation

137 (CV). Model spatial transferability was evaluated using a spatially constrained 10-fold

$138 \mathrm{CV}$ (details in SI). For each model, the averaged relative importance (ARI) of each

139 variable in the model was calculated with an input permutation technique and one-

140 factor-at-a-time (OFAT) sensitivity analysis (details in SI). The complete modelling

141 framework to select variables, calibrate the model and predict $\mathrm{Cu}_{\mathrm{t}}$ is available for

142 download at https://github.com/Boris-Droz/ML_soil_predi_conc. 
146 Copper Accumulation and Export.

$147 \mathrm{Cu}_{\mathrm{t}}$ net mass accumulation since the beginning of the $\mathrm{Cu}_{\mathrm{f}}$ application was estimated 148 assuming that $\mathrm{Cu}_{\mathrm{t}}$ is distributed similarly across a homogenous topsoil layer, following 149 eq. 1 ,

150 net acc. $=\left(C u_{\text {Pred }}-C u_{\text {bgd }}\right) \times B D \times h_{\text {topsoil }}(1)$

151 where net acc. stands for the $\mathrm{Cu}_{\mathrm{t}}$ net mass accumulation (kg $\left.\mathrm{Cu} \mathrm{ha}{ }^{-1}\right), C u_{b g d}$ the 152 background of geogenic and atmospheric non-agricultural anthropogenic $\mathrm{Cu}_{\mathrm{t}}(\mathrm{mg} \mathrm{Cu}$ $153 \mathrm{~kg}^{-1} ; \mathrm{SI}$, Figure S2), $B D$ is the soil bulk density (https://soilgrids.org/, series $\mathrm{M} \_$sl1, $154 \mathrm{v} 18.4 .2017$; in $\left.\mathrm{kg} \mathrm{m}^{-3}\right)^{40}$ and the average topsoil thickness where $\mathrm{Cu}$ mainly 155 accumulates $\left(h_{\text {topsoil }}=30 \mathrm{~cm} ; \mathrm{SI}\right.$, Table S1). The net mass export of $\mathrm{Cu}_{\mathrm{t}}($ net exp.; $\mathrm{kg}$ of $156 \mathrm{Cu} \mathrm{ha}{ }^{-1}$ ) was assumed to be the sum of $\mathrm{Cu}_{t}$ exported from topsoil via runoff and 157 leaching, and was calculated yearly following eq. $2,{ }^{13,14}$

158 net exp. $=\left(\dot{q}_{R U S L E}+f_{\text {sol }} \times B D \times h_{\text {topsoil }}\right) \times C u_{\text {Pred }}(2)$

159 where $\dot{q}_{R U S L E}$ is the soil loss rate $\left(\mathrm{kg} \mathrm{ha}^{-1}\right)$ as defined elsewhere ${ }^{21}$ and $f_{\text {sol }}$ the soluble 160 fraction of $C u_{\text {Pred }}$ estimated from soil properties (both details in SI).

\section{Scenarios of Copper-Based Fungicides Application Doses.}

163 Four scenarios of $\mathrm{Cu}_{\mathrm{f}}$ application doses were compared: (i) an historical scenario with $1648 \mathrm{~kg} \mathrm{Cu} \mathrm{ha}$ year $^{-1}$ inferred from sold $\mathrm{Cu}_{\mathrm{f}}$ amount before the 2002 European 165 regulation, ${ }^{2}$ and/or speculated illegal usage in some areas, ${ }^{41}$ (ii) current regulation 166 scenarios, with either (iii) 2 or (iii) $4 \mathrm{~kg} \mathrm{Cu} \mathrm{ha}^{-1}$ year $^{-1}$ as average and maximum doses, 
167 respectively, ${ }^{2,42}$ and (iv) a scenario of $\mathrm{Cu}_{f}$ substitution, i.e., no $\mathrm{Cu}_{f}$ application or $0 \mathrm{~kg} \mathrm{Cu}$ $168 \mathrm{ha}^{-1}$ year $^{-1}$.

169 For the scenario with $8 \mathrm{~kg} \mathrm{Cu} \mathrm{ha}^{-1}$ year $^{-1}$ and current regulation scenarios, a stepwise 170 mass balance calculation based on a year $\mathrm{t}$ was established (eq. 3 and detail in $\mathrm{SI}$ ) 171 assuming no temporal variation of the topsoil volume and a homogeneous topsoil layer $172(0-30 \mathrm{~cm})$,

$173 C u_{\text {pred }, t+1}=C u_{\text {pred }, t}+\left(A P P_{C u, f}-C u_{\text {pred }, t} \times\right.$ net exp. $\left.-C u_{\text {input }} \times f_{\text {sol }}\right) /\left(B D \times h_{\text {topsoil }}\right)$

174 where $\mathrm{Cu}_{\text {pred }}$ is the average predictions of $\mathrm{Cu}_{\mathrm{t}}\left(\mathrm{mg} \mathrm{Cu} \mathrm{kg}{ }^{-1}\right), A P P_{C u, f}$ the yearly 175 application dose of $\mathrm{Cu}_{\mathrm{f}}\left(\mathrm{kg} \mathrm{Cu} \mathrm{ha}^{-1}\right.$ year $\left.^{-1}\right)$ and $f_{\text {sol }}$ the soluble fraction as calculated in 176 eq S3-6. The net exp. was previously calculated in eq. 2. $C u_{p r e d, t+1}$ accounted for the 177 yearly $\mathrm{Cu}$ application dose to which the soluble fraction of $\mathrm{Cu}_{\mathrm{f}}\left(f_{\text {sol }}\right)$ and the net exp. 178 were deducted. For each, pixel, the scenario was applied until $\mathrm{Cu}_{\text {pred }}$ at year $t+1$ 179 reaches for the given pixel the predicted no-effect concentration (PNEC; SI, building 180 spatial variables). In contrast, the time required to export the accumulated $\mathrm{Cu}_{\mathrm{f}}$ via runoff 181 and associated suspended solids and reach back $C u_{b g d}$, i.e., assuming the existence of 182 alternatives to $\mathrm{Cu}_{\mathrm{f}}$, was estimated by dividing eq. 1 by eq. 2.

183 The uncertainty associated with each scenario was estimated by numerical 184 propagation of uncertainties across the entire modelling framework. Briefly, each 185 variable was associated with lower and an upper uncertainty limits accounting for the 186 analytical or monitoring uncertainty or calculation steps, depending on the variable (SI, 187 Table S4). All combinations of lower and upper uncertainty limits for the selected 188 variables were then included to propagate uncertainties and estimate the lower and 189 upper uncertainty limits associated to each scenario for each pixel independently. 
192 RESULTS AND DISCUSSION

193 Prediction of Total Copper in Topsoil.

194 Ten variables governing $\mathrm{Cu}_{t}$ in vineyard topsoil were considered (see above Materials 195 and Methods and SI, Figure S4. b). Using these climate and soil variables, the ENS 196 accurately predicted $\mathrm{Cu}_{t}$ (slope of 1.13 , intercept of 0.01 ; SI, Figure S4. a), and

197 predictions were fairly precise (averaged $\mathrm{R}^{2}=0.61$ ). Comparison between ENS and CV 198 (averaged $\mathrm{R}^{2}-\mathrm{CV}=0.58 \pm 0.06$ ) indicates no over-fitting of the ENS. For the three 199 machine learning technics, $\mathrm{Cu}_{\text {pred }}$ fit $\mathrm{Cu}_{\mathrm{t}}$, dat $\left(\mathrm{SD} \mathrm{Cu}_{\text {pred }} / \mathrm{Cu}_{\mathrm{t}}\right.$, dat $\times 100=13 \pm 2 \%$ ), 200 indicating a good overall agreement of predictions between the three technics. Average 201 uncertainty of the $\mathrm{Cu}_{\text {pred }}$ falls within $\pm 11 \mathrm{mg} \mathrm{Cu} \mathrm{kg}^{-1}$ for $75 \%$ of the data (RMSE of 0.63 $202 \pm 0.06)$. The scattering observed in the predictions (SI, Figure S4) mainly concerns data 203 above $130 \mathrm{mg} \mathrm{Cu} \mathrm{kg}^{-1}$, corresponding to $6.3 \%$ of the dataset only. ENS predictions 204 failed to reproduce observed $\mathrm{Cu}_{t}$ in the corresponding vineyard areas, which potentially 205 received larger historical $\mathrm{Cu}_{\mathrm{f}}$ applications than other areas under similar climatic and 206 soil conditions. Additional model performances and limits are provided in SI.

208 Climate Variables rather than Soil Variables Determine Total Copper in Topsoil.

209 Climate variables (i.e., rainfall and aridity index) mainly determined $\mathrm{Cu}_{\text {pred }}$ at the 210 European scale, possibly by controlling physicochemical processes, including $\mathrm{Cu}$ 211 leaching and the redox state of soil. Hydro-climatic conditions likely determined regional 212 Cu application practices as 'Downy Mildew's' pressure increases in more humid and 
213 warmer areas in early summer..$^{30,31}$ In contrast, soil physicochemical properties (i.e., pH)

214 predominantly governed $\mathrm{Cu}_{t}$ on the local scale and under homogeneous climatic

215 conditions. The averaged relative importance (ARI) from the ENS and the sensitivity

216 analyses confirmed the relationship between climate variables and $\mathrm{Cu}_{\text {pred. }} \mathrm{Cu}$ pred

217 correlated positively with both the annual rainfall (rain; $R^{2}=0.71$ ) and the aridity index

218 (Al; potential evapotranspiration divided by rainfall; $\mathrm{R}^{2}=0.79$ ), while the combined

219 effect of rainfall and $\mathrm{Al}$ accounted for $32.6 \%$ of the $\mathrm{Cu}_{\text {pred }} \mathrm{ARI}$ (rainfall $=17.4 \pm 0.9 \%, \mathrm{Al}$

$220=15.2 \pm 1.3 \%$; SI, Figure S4. b).

221 Although rainfall was negatively correlated with $\mathrm{Al}$, both variables were positively

222 correlated to $\mathrm{Cu}_{\text {pred }}$, suggesting that two different mechanisms control $\mathrm{Cu}_{\mathrm{t}}$ in vineyard

223 soil. First, rainfall could increase temporally soil water content and reduce oxygen

224 diffusion in water, leading to reducing soil conditions. ${ }^{43}$ Under anoxic conditions,

225 biological activity may decrease $\mathrm{Cu}$ mobility by precipitating soluble $\mathrm{Cu}(\mathrm{II})$ to $\mathrm{Cu}(\mathrm{I}),{ }^{44,45}$

226 which is strongly complexed and stabilized with reduced organic sulfur. ${ }^{46}$ Additionally,

227 depending on the solutes present in soil, e.g., carbonate, sulphide, biotic and abiotic

228 processes may form minerals and further reduce the $\mathrm{Cu}_{\mathrm{t}}$ mobility. ${ }^{33,47,48}$

229 In contrast, higher Al leads to drier soil, ${ }^{49}$ which facilitates the formation of soil

230 macropores favoring oxygen transfer. ${ }^{50}$ As a result, $\mathrm{Cu}(\mathrm{I})$ may partly re-oxidize into

231 mobile $\mathrm{Cu}(\mathrm{II})$ in oxic soil. However, an opposite trend is observed as Al may indirectly

232 increase the Cu-binding affinity of soil organic matter (ARI of $13.1 \pm 0.1 \%$ ). Indeed, the

233 oxidation of organic matter under oxic conditions increases the contribution of carboxylic

234 and hydroxylic groups as preferential binding partners for $\mathrm{Cu}$ in organic matter. ${ }^{51}$ In 
235 addition, $\mathrm{pH}(\mathrm{ARI}$ of $7.5 \pm 1.3 \%$ ) directly controls the deprotonation of sorption sites on

236 soil constituent. Hence, higher $\mathrm{pH}$ increases available sorption sites for $\mathrm{Cu}$ binding. ${ }^{19}$

237

238 Distribution of the Total Copper in Topsoil Across European Vineyards.

$239 \mathrm{Cu}_{\text {pred }}$ in European vineyards were successfully made as the datasets covered the

240 range of predictive variables within the domain of prediction. The ENS also displays

241 good model transferability in space evaluated on four equivalent geographical sub-

242 domains (average $\mathrm{R}^{2}=0.84 \pm 0.07$, details in $\mathrm{SI}$ ). This suggests a homogenous

243 influence of predictive variables within the European vineyards. Overall, $\mathrm{Cu}_{\text {pred }}$ for

244 vineyards is $25.4 \mathrm{mg} \mathrm{Cu} \mathrm{kg}^{-1}$ which is $30.5 \%$ higher than $\mathrm{Cu}_{\text {bgd }}$ including geogenic and

245 atmospheric non-agricultural anthropogenic $\mathrm{Cu}$ (Figure 1. a-b). 


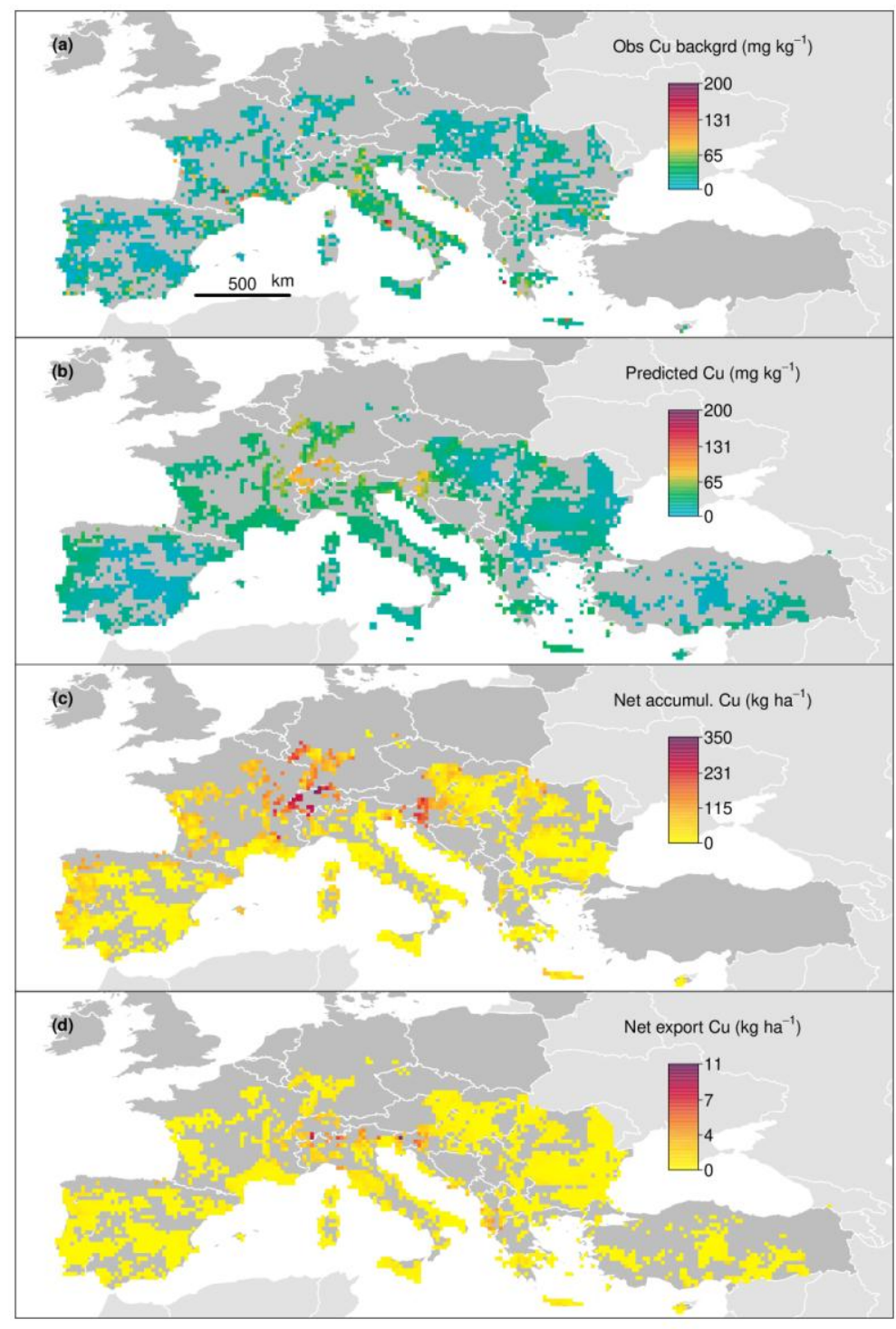

248 Figure 1. Distribution of the total copper content in vineyard topsoil $\left(\mathrm{Cu}_{\mathrm{t}}\right)$, accumulation 249 and net export of $\mathrm{Cu}$ in European Vineyards. (a) Observed background $\mathrm{Cu}_{\mathrm{t}}$. (b) 250 Predicted $\mathrm{Cu}_{\mathrm{t}}\left(\mathrm{Cu}_{\mathrm{pred}}\right)$. (c) Estimated net accumulation of $\mathrm{Cu}_{\mathrm{t}}$ (d) Estimated net export of $251 \mathrm{Cu}_{\mathrm{t}}$. Dark grey: Area of the European Corine Land Cover (CLC). Pixels depict average 252 predictive values at a spatial resolution of $20 \mathrm{~km}^{2}$. Net accumulation was not computed 253 for Turkey due to absence of background data. Overall, $\mathrm{Cu}_{\text {pred }}$ were higher for vineyards 
254 in the alpine regions (Figure 1. b; average $=57 \mathrm{mg} \mathrm{Cu} \mathrm{kg}^{-1}$ ) than in other European 255 biogeographic regions (SI, Table S5).

257 The threshold of contamination $\left(>100 \mathrm{mg} \mathrm{Cu} \mathrm{kg}^{-1}\right)^{5}$ was reached for $2 \%$ of $\mathrm{Cu}_{\text {pred }}$ 258 within the prediction domain. Contaminated areas were mainly located in central 259 Western Europe, i.e., northern Italy, eastern France, Switzerland and Slovenia. In those 260 regions, $\mathrm{C}_{\text {org }}$ is medium (up to $14 \%$ ) while $\mathrm{Cu}_{\text {pred }}>100 \mathrm{mg} \mathrm{Cu} \mathrm{kg}^{-1}$ accounted for $70 \%$ of 261 vineyard soil. ${ }^{52}$ Data points above the contamination threshold in those regions are 262 characterized by high $\mathrm{Al}$, soil moisture and annual rainfall, although only $\mathrm{C}_{\text {org }}$ was 263 significantly higher $(>9.0 \%)$ than in other regions of southern Europe (t-test; $p$-value $264<0.01)$. This suggests that higher annual rainfall correlates with higher temperature in 265 central Western Europe. This may favor 'Downy Mildew' emergence and concomitant 266 use of higher doses and more frequent applications of $\mathrm{Cu}_{f}$. In central Western Europe, 267 soil with higher $\mathrm{C}_{\text {org }}$ may influence the $\mathrm{Cu}_{\text {pred }}$ predominantly and locally, although $\mathrm{C}_{\text {org }}$ 268 accounted in total for $13.1 \% \mathrm{ARI}$ of the $\mathrm{Cu}_{\text {pred. }}$

270 Accumulation and Export of Copper in Topsoil.

271 The estimated average net accumulation and net export of $\mathrm{Cu}$ in topsoil in European 272 vineyards are $24.8(\mathrm{SD}=42.7)$ and $0.29 \mathrm{~kg} \mathrm{Cu} \mathrm{ha}^{-1}(\mathrm{SD}=0.64)$, respectively (Figure 1 273 C-d). This corresponds to 112,400 tons of $\mathrm{Cu}$ accumulated over time, and a yearly $\mathrm{Cu}$ 274 export from vineyards of 1,466 tons across Europe. The distribution of $\mathrm{Cu}$ net export 275 fitted with that of $\mathrm{Cu}_{\text {pred }}\left(\mathrm{R}^{2}=0.65\right)$. On average, predicted loss rate of vineyard soil 276 (9.47 tons $\mathrm{ha}^{-1}$ year $\left.^{-1}\right)$ is 3.5 times greater than any other European arable land due to 
277 low vegetation and sloping area in vineyards. Consequently, net $\mathrm{Cu}$ export is 278 particularly large in the Southern Alps due to intense soil erosion. Large soil loss is 279 associated to higher slope $\left(>25^{\circ}\right)$ and greater rainfall amounts $\left(>1,600 \mathrm{~mm}\right.$ year $\left.{ }^{-1}\right)$ in 280 the Southern Alps than in other vineyard areas. ${ }^{21}$

282 Potential Future Copper Accumulation in European Vineyards.

283 Overall, the proportion of European vineyard area exceeding PNEC values (i.e.,

284 ranged from 30 to $290 \mathrm{mg} \mathrm{Cu} \mathrm{kg}^{-1}$ according to soil properties calculate elsewhere, ${ }^{53,54}$ 285 details in $\mathrm{SI}$ ) may largely vary in the future depending on the application dose of $\mathrm{Cu}_{\mathrm{f}}$ 286 (Figure 2). Cu accumulation due to $\mathrm{Cu}_{\mathrm{f}}$ application doses of 2, 4 and $8 \mathrm{~kg} \mathrm{Cu} \mathrm{ha}^{-1}$ year $^{-1}$ 287 may be balanced with $\mathrm{Cu}$ export after 1,200, 750 and 150 years, with $75,89,97 \%$ of 288 European vineyards areas exceeding PNEC values, respectively. Assuming constant 289 soil properties, we speculate that the current European regulation with a maximum 290 application of $4 \mathrm{~kg} \mathrm{Cu} \mathrm{ha}^{-1}$ year $^{-1}$ will increase by only $2 \%$ the proportion of vineyard 291 areas exceeding PNEC in the next 100 years.

292 In contrast, 94\% of vineyard areas may exceed PNEC in the historical application 293 scenario of $8 \mathrm{~kg} \mathrm{Cu} \mathrm{ha}^{-1}$ year $^{-1}$. With an application of $2 \mathrm{~kg} \mathrm{Cu} \mathrm{ha}^{-1}$ year $^{-1}$, vineyards 294 areas exceeding PNEC values may increase by less than $0.5 \%$ for the next 100 years. 295 In contrast, a substitution of $\mathrm{Cu}_{\mathrm{f}}\left(0 \mathrm{~kg} \mathrm{Cu} \mathrm{ha}^{-1}\right.$ year $\left.^{-1}\right)$ may decrease the proportion of 296 vineyard areas exceeding the background $\mathrm{Cu}_{\text {bgd }}$ from 48 to $38 \%$ after 100 years. Such 297 long-term indicative estimation for different $\mathrm{Cu}$ application dose provides critical 298 temporal trend to support the reduction of Cu application in vineyard. 


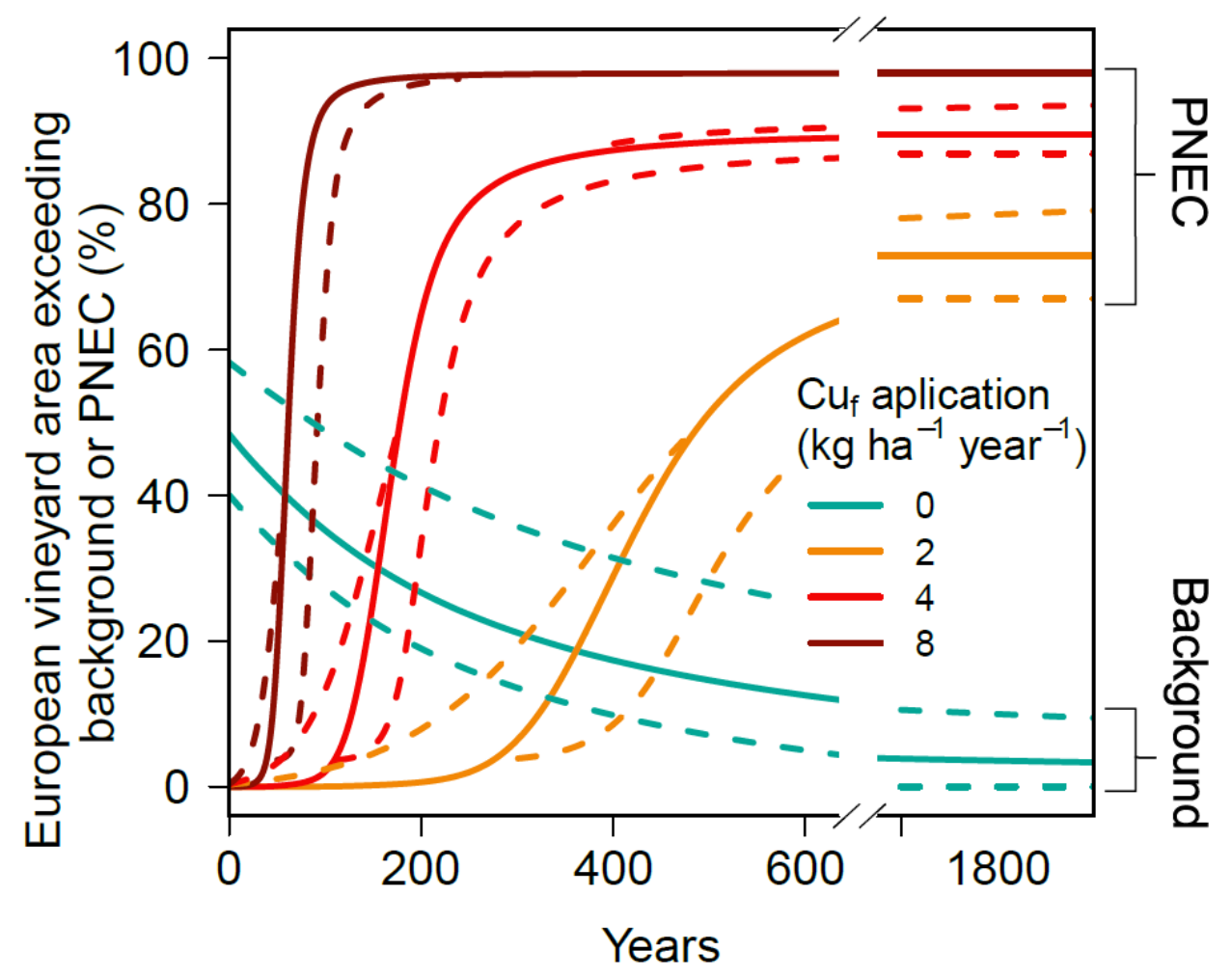

300 Figure 2. Proportion of European vineyards area exceeding predicted no-effect 301 concentration (PNEC) values of total $\mathrm{Cu}$ in topsoil (scenarios with $\mathrm{Cu}_{\mathrm{f}}$ application dose 302 of 2, 4, $8 \mathrm{~kg} \mathrm{ha}^{-1}$ year $^{-1}$ ) or equal to or lower than the background (bgd) Cu content 303 (scenario with no $\mathrm{Cu}_{\mathrm{f}}$ application). Predictions account for the balance between yearly $304 \mathrm{Cu}_{\mathrm{f}}$ application at a given application dose and $\mathrm{Cu}$ export over time. Dashed lines 305 indicate the upper and lower uncertainties of predictions.

307 Our back-envelope is a first attempt to evaluate $\mathrm{Cu}$ accumulation and export at the 308 European scale and the proposed mass balance approach may lead to inaccurate 309 estimations of $\mathrm{Cu}_{t}$ export. For instance, freshly applied $\mathrm{Cu}_{\mathrm{f}}$ is a soluble $\mathrm{Cu}$ pool that can 310 be directly exchanged with the labile cation present in vineyard soil following $\mathrm{Cu}_{f}$ 
311 application. Depending on the time following $\mathrm{Cu}_{f}$ application, $\mathrm{Cu}_{\mathrm{f}}$ may be partly mobilized

312 during rainfall-runoff events ${ }^{14}$ and thus bias estimations of $\mathrm{Cu}_{t}$ in soil. Since rainfall

313 erosivity is predicted to increase by $18 \%$ in Europe over time, $\mathrm{Cu}_{\mathrm{f}}$ export may also

314 increase.$^{55}$ In addition, estimations using the semi empirical model account for $\mathrm{Cu}$ aging

315 in contaminated soil and rely on realistic desorption experiments, which may

316 underestimate $\mathrm{Cu}_{f}$ export. ${ }^{12}$ However, $\mathrm{Cu}_{f}$ accumulation over time may be also

317 underestimated. Climate change models predict an average of $10 \%$ increase of soil

318 organic matter content by 2100 in regions of European vineyards ${ }^{56}$ which may in turn

319 reduce $\mathrm{Cu}_{\mathrm{t}}$ mobility and increase the amount of $\mathrm{Cu}$ accumulated in the vineyard soil.

$321 \quad$ Implications for Winegrowing Practices.

$322 \mathrm{Cu}$ is an element that cannot be degraded in soil and soil remediation processes, 323 such as phyto-extraction ${ }^{57}$ or enhanced mobilization by plants, ${ }^{58}$ have limited 324 efficiencies. The most efficient strategies to limit the increase of $\mathrm{Cu}_{t}$ is thus to reduce 325 application doses of $\mathrm{Cu}_{f}$. Reducing strategies consist in applying $\mathrm{Cu}_{\mathrm{f}}$ during long humid 326 periods only ${ }^{42}$ and in reducing preventively the use of $\mathrm{Cu}_{\mathrm{f}}$. Forecast models of 327 grapevine 'Downy Mildew ${ }^{59}$ relying on climate variables can help to improve the 328 efficiency of $\mathrm{Cu}_{\mathrm{f}}$ reduction strategies. Alternatives to $\mathrm{Cu}_{\mathrm{f}}$ include replacing current grape 329 varieties with new grape varieties with a higher resistance to fungus pests, ${ }^{60}$ using 330 microorganisms for biocontrol, ${ }^{61}$ introducing plant defense stimulators ${ }^{62}$ and/or applying 331 plant extracts to substitute $\mathrm{Cu}_{\mathrm{f}}{ }^{63}$ Alternative scenarios without $\mathrm{Cu}_{\mathrm{f}}$ are still debated, but 332 are currently used in some Biodynamic approaches accounting for only ca. $1 \%$ of 333 vineyards worldwide (http://www.demeter.net). Additional benefits of biodynamic wine 
334 growing include the higher soil biodiversity and microbiological activity ${ }^{10}$ and potentially 335 greater resilience to climatic and pathogenic threats in vineyards ${ }^{64}$ as opposed to most 336 conventional wine growing. ${ }^{65}$

337 Cu export is mainly driven by soil erosion with concomitant loss of solid-bound $\mathrm{Cu}$, 338 which should be prevented and lessened in regions prone to soil loss to reduce 339 contamination of connected aquatic ecosystems. In fact, $10 \%$ of the vineyards are 340 located close to a river $(<500 \mathrm{~m})^{66}$ and the associated catchment may act as a point

341 source of contamination. The transport of solid-bound $\mathrm{Cu}$ into aquatic ecosystems may

342 also affect the downstream areas due to the progressive release of toxic $\mathrm{Cu}(\mathrm{II})$ resulting 343 from a change in $\mathrm{pH}$ and/or redox conditions. Anti-erosion soil management strategies 344 should thus be prioritized and designed to retain $\mathrm{Cu}$ on the vineyard plots. In particular, 345 traditional soil management strategies, including grass or mulch cover, reduced tillage, 346 contour planting and terraced vineyards are most effective in limiting soil erosion and 347 associated $\mathrm{Cu}$ runoff. ${ }^{35}$ Complementarily, stormwater wetlands may be deployed at the 348 outlet of vineyard catchments. Stormwater wetlands have the potential to retain $>68 \%$ of 349 the dissolved $\mathrm{Cu}$ and $>92 \%$ of the solid-bound $\mathrm{Cu}$, the principal contributions to $\mathrm{Cu}$ 350 export in runoff. ${ }^{14}$

352 ASSOCIATED CONTENT

353 Supporting Information

354 The Supporting Information is available free of charge on the ACS Publications 355 website at DOI: XXX/XXXXX. 
356 Texts, tables, and figures provide detailed methods (total copper in the topsoil dataset,

357 spatial variable building, data pre-processing, variable selection, machine learning

358 building, performance and evaluation, scenario of copper-based fungicide application)

359 and supporting results and discussion (model performance, regional prediction, limit of 360 the approach).

361

362 AUTHOR INFORMATION

363 * Corresponding author. e-mail: bodroz@bluewin.ch; imfeld@unistra.fr phone: + 333

$364 \quad 68850474$

365 ORCID

366 Boris Droz: 0000-0002-3942-704X

367 Sylvain Payraudeau: 0000-0003-2546-7857

368 José Antonio Rodríguez Martín: 0000-0002-9158-9564

369 Gergely Tóth: 0000-0002-4201-1678

370 Panos Panagos: 0000-0003-1484-2738

371 Luca Montanarella: 0000-0002-4176-3878

372 Pasquale Borrelli: 0000-0002-4767-5115

373 Gwenaël Imfeld: 0000-0002-7054-4666

374

375 Author contributions

376 B.D., S.P. and G.I. designed research, B.D. performed research; S.P., J.A., R.M., G.T.,

377 P.P., L. M. and P.B. contributed to the acquisition of data/soil samples; B.D. and S.P. 
378 analyzed data; and B.D., S.P. and G.I. wrote the manuscript with critical review from all

379 authors. The authors declare no conflict of interest.

381 ACKNOWLEDGEMENTS

382 Boris Droz was supported by a fellowship of the Region Grand Est and the Rhine-

383 Meuse Water Agency (AERM). Pasquale Borrelli was funded by the EcoSSSoil Project, 384 Korea Environmental Industry \& Technology Institute (KEITI), Korea (Grant No. 385 2019002820004). We acknowledge the copper dataset owners for sharing their data: 386 Holger Tülp (Mosel, Germany), Denis Rusjan (Slovenia), Maria Concepcion Ramos 387 (Spain), Nikolai Dinev (Bulgaria), several Swiss state environmental agencies 388 (Schaffhausen, Neuchâtel, Genève, Tecino, Aargau, Valais), Central Institute for 389 Supervising and Testing in Agriculture (ÚKZÚZ, Czech Republic), Bundesanstalt für

390 Geowissenschaften und Rohstoffe (Germany), le Réseau de Mesures de la Qualité des 391 Sols (RMQS) de I'Institut National de Recherche pour l'Agriculture, I'Alimentation et 392 l'Environnement (INRAE, France). We acknowledge Koens Oorts to sharing the 393 toxicological Model. The LUCAS topsoil dataset, CORINE land cover and Copernic data 394 were funded by the European Environment Agency (EEA). MODIS data was supported 395 by the NASA EOSDIS Land Processes Distributed Active Archive Center (LP DAAC), 396 USGS/Earth Resources Observation and Science (EROS). We acknowledge Dimitri 397 Rambourg, Raphaël di Chiara, Marwan Fahs, Gerhard Schäfer and Benoit Masson398 Bedeau for enable computing time. We gratefully acknowledge Margaret Johnson for 
399 enabling significant improvement of the manuscript. Finally, we thank the two 400 anonymous reviewers and Guillaume Drouin for useful comments. 
1. Borkow, G.; Gabbay, J., Copper, an ancient remedy returning to fight microbial, fungal and viral infections. Curr. Chem. Biol. 2009, 3, (3), 272-278.

2. Commission Implementing regulation (EU), 2018/1981 renewing the approval of

3. Lamichhane, J. R.; Osdaghi, E.; Behlau, F.; Köhl, J.; Jones, J. B.; Aubertot, J.-N., Thirteen decades of antimicrobial copper compounds applied in agriculture. A review. Agron. Sustain. Dev. 2018, 38, (3), 28-45.

4. Ballabio, C.; Panagos, P.; Lugato, E.; Huang, J.-H.; Orgiazzi, A.; Jones, A.; Fernández-Ugalde, O.; Borrelli, P.; Montanarella, L., Copper distribution in European topsoils: An assessment based on LUCAS soil survey. Sci. Total Environ. 2018, 636, 282-298.

5. Ministry of the Environment Finland Government decree on the assessment of soil contamination and remediation needs; Finland, 2007.

6. SCHER Voluntary risk assessment report on copper and its compounds, environmental

part;

2009. 
http://echa.europa.eu/chem data/transit measures/vrar en.asp (14 $^{\text {th }}$ January 2021).

7. OIV World vitiviniculture situation, OIV statistical report on world vitiviniculture; Organisation Internationale de la Vigne et du Vin: Paris, France, 2016; p 16.

8. Nadin, P.; Eurostat, The use of plant protection products in the European Union data 1992-2003. Office for Official Publications of the European Communities: Luxembourg, 2007.

9. Flemming, C. A.; Trevors, J. T., Copper toxicity and chemistry in the environment: a review. Water, Air, Soil Pollut. 1989, 44, (1), 143-158.

10. Maeder, P.; Fliessbach, A.; Dubois, D.; Gunst, L.; Fried, P.; Niggli, U., Soil fertility and biodiversity in organic farming. Science 2002, 296, (5573), 1694-1697.

11.Hendgen, M.; Hoppe, B.; Döring, J.; Friedel, M.; Kauer, R.; Frisch, M.; Dahl, A.; Kellner, H., Effects of different management regimes on microbial biodiversity in vineyard soils. Sci. Rep. 2018, 8, (1), 9393-9406.

12. McBride, M.; Sauve, S.; Hendershot, W., Solubility control of Cu, Zn, Cd and Pb

14.Babcsányi, I.; Imfeld, G.; Granet, M.; Chabaux, F., Copper stable isotopes to trace copper behavior in wetland systems. Environ. Sci. Technol. 2014, 48, (10), $5520-5529$. 
15. Roussiez, V.; Probst, A.; Probst, J.-L., Significance of floods in metal dynamics and export in a small agricultural catchment. J. Hydrol. 2013, 499, 71-81.

16.Schwarzenbach, R. P.; Egli, T.; Hofstetter, T. B.; von Gunten, U.; Wehrli, B., Global water pollution and human health. Annu. Rev. Env. Resour. 2010, 35, $109-136$.

17. Strawn, D. G.; Baker, L. L., Speciation of $\mathrm{Cu}$ in a contaminated agricultural soil

19. Sposito, G., The chemistry of soils. second ed.; Oxford University Press: 2008. along rainfall and topographic gradients in upland wet tropical forest soils. Biogeochemistry 1999, 44, (3), 301-328.

21. Borrelli, P.; Robinson, D. A.; Fleischer, L. R.; Lugato, E.; Ballabio, C.; Alewell, C.; Meusburger, K.; Modugno, S.; Schütt, B.; Ferro, V.; Bagarello, V.; Oost, K. V.; Montanarella, L.; Panagos, P., An assessment of the global impact of 21st century land use change on soil erosion. Nat. Commun. 2017, 8, (1), 2013.

22. Reimann, C.; de Caritat, P., New soil composition data for Europe and Australia: Demonstrating comparability, identifying continental-scale processes and 
learning lessons for global geochemical mapping. Sci. Total Environ. 2012, 416, 239-252.

23. Ander, E. L.; Johnson, C. C.; Cave, M. R.; Palumbo-Roe, B.; Nathanail, C. P.; Lark, R. M., Methodology for the determination of normal background concentrations of contaminants in English soil. Sci. Total Environ. 2013, 454 $455,604-618$.

24.Panagos, P.; Ballabio, C.; Lugato, E.; Jones, A.; Borrelli, P.; Scarpa, S.; Orgiazzi, A.; Montanarella, L., Potential sources of anthropogenic copper inputs to european agricultural soils. Sustainability 2018, 10, 2380-2397.

25. Chopin, E. I. B.; Alloway, B. J., Distribution and mobility of trace elements in soils and vegetation around the mining and smelting areas of Tharsis, Ríotinto and Huelva, Iberian Pyrite Belt, SW Spain. Water, Air, Soil Pollut. 2007, 182, (1), 245-261.

26. Wilson, B.; Pyatt, F. B., Heavy metal dispersion, persistance, and bioccumulation around an ancient copper mine situated in Anglesey, UK. Ecotoxicol. Environ. Saf. 2007, 66, (2), 224-231.

27. Orchard, V. A.; Cook, F. J., Relationship between soil respiration and soil moisture. Soil Biol. Biochem. 1983, 15, (4), 447-453. Voegelin, A.; Campbell, K., Biogeochemical redox processes and their impact on contaminant dynamics. Environ. Sci. Technol. 2010, 44, (1), 15-23. 
29.Donner, E.; Howard, D. L.; Jonge, M. D. d.; Paterson, D.; Cheah, M. H.; Naidu, R.; Lombi, E., X-ray absorption and micro X-ray fluorescence spectroscopy investigation of copper and zinc speciation in biosolids. Environ. Sci. Technol.

30. Besnard, E.; Chenu, C.; Robert, M., Influence of organic amendments on copper

31.Komárek, M.; Čadková, E.; Chrastný, V.; Bordas, F.; Bollinger, J.-C., Contamination of vineyard soils with fungicides: A review of environmental and toxicological aspects. Environ. Int. 2010, 36, (1), 138-151.

32. Mora, C.; Caldwell, I. R.; Caldwell, J. M.; Fisher, M. R.; Genco, B. M.; Running, S. W., Suitable days for plant growth disappear under projected climate change: potential human and biotic vulnerability. PLoS Biol. 2015, 13, (6), e1002167.

33. Brun, L. A.; Maillet, J.; Richarte, J.; Herrmann, P.; Remy, J. C., Relationships between extractable copper, soil properties and copper uptake by wild plants in vineyard soils. Environ. Pollut. 1998, 102, (2-3), 151-161.

34. Miotto, A.; Ceretta, C. A.; Brunetto, G.; Nicoloso, F. T.; Girotto, E.; Farias, J. G.; Tiecher, T. L.; De Conti, L.; Trentin, G., Copper uptake, accumulation and physiological changes in adult grapevines in response to excess copper in soil. Plant Soil 2014, 374, (1), 593-610. 
35.Durán Zuazo, V. H.; Rodríguez Pleguezuelo, C. R., Soil-erosion and runoff prevention by plant covers. A review. Agron. Sustain. Dev. 2008, 28, (1), 65-86.

36.Schmidt, M. W. I.; Torn, M. S.; Abiven, S.; Dittmar, T.; Guggenberger, G.; Janssens, I. A.; Kleber, M.; Kogel-Knabner, I.; Lehmann, J.; Manning, D. A. C.; Nannipieri, P.; Rasse, D. P.; Weiner, S.; Trumbore, S. E., Persistence of soil organic matter as an ecosystem property. Nature 2011, 478, (7367), 49-56.

37. Araujo, M. B.; Guisan, A., Five (or so) challenges for species distribution modelling. J. Biogeogr. 2006, 33, (10), 1677-1688.

38. Press, W. H.; Teukolsky, S. A.; Vetterling, W. T.; Flannery, B. P., Numerical recipes in C: The art of scientific computing. Cambridge University Press: 2002.

39. Dietterich, T. G., Ensemble methods in machine learning. In Proceedings of the first international workshop on multiple classifier systems, Springer-Verlag: New York, NY, 2000.

40. Hengl, T.; Mendes de Jesus, J.; Heuvelink, G. B. M.; Ruiperez Gonzalez, M.; Kilibarda, M.; Blagotić, A.; Shangguan, W.; Wright, M. N.; Geng, X.; BauerMarschallinger, B.; Guevara, M. A.; Vargas, R.; MacMillan, R. A.; Batjes, N. H.; Leenaars, J. G. B.; Ribeiro, E.; Wheeler, I.; Mantel, S.; Kempen, B., SoilGrids250m: Global gridded soil information based on machine learning. PLoS One 2017, 12, (2), e0169748. mini review. Environ. Pollut. 2012, 167, 16-26. 
42.Speiser, B.; Mieves, E.; Tamm, L., Utilisation de cuivre par les paysans bio suisses dans différentes cultures. Rech. Agr. Suisse 2015, 6, (4), 160-165.

43. Liptzin, D.; Silver, W. L.; Detto, M., Temporal dynamics in soil oxygen and greenhouse gases in two humid tropical forests. Ecosystems 2011, 14, (2), 171182.

44. Hofacker, A. F.; Behrens, S.; Voegelin, A.; Kaegi, R.; Losekann-Behrens, T.; Kappler, A.; Kretzschmar, R., Clostridium species as metallic copper-forming bacteria in soil under reducing conditions. Geomicrobiol. J. 2015, 32, (2), 130 139.

45. Weber, S. D.; Hofmann, A.; Pilhofer, M.; Wanner, G.; Agerer, R.; Ludwig, W.; Schleifer, K. H.; Fried, J., The diversity of fungi in aerobic sewage granules assessed by $18 \mathrm{~S}$ rRNA gene and ITS sequence analyses. FEMS Microbiol. Ecol. 2009, 68, (2), 246-254.

46. Fulda, B.; Voegelin, A.; Maurer, F.; Christl, I.; Kretzschmar, R., Copper redox transformation and complexation by reduced and oxidized soil humic acid. 1. Xray absorption spectroscopy study. Environ. Sci. Technol. 2013, 47, (19), 1090310911.

47.Ponizovsky, A. A.; Allen, H. E.; Ackerman, A. J., Copper activity in soil solutions of calcareous soils. Environ. Pollut. 2007, 145, (1), 1-6.

48. Pattrick, R. A. D.; Mosselmans, J. F. W.; Charnock, J. M.; England, K. E. R.; Helz, G. R.; Garner, C. D.; Vaughan, D. J., The structure of amorphous copper 
sulfide precipitates: An X-ray absorption study. Geochim. Cosmochim. Acta 1997, 61, (10), 2023-2036.

49. Jarvis, N. J., A review of non-equilibrium water flow and solute transport in soil macropores: principles, controlling factors and consequences for water quality.

50. Katuwal, S.; Arthur, E.; Tuller, M.; Moldrup, P.; de Jonge, L. W., Quantification of Eur. J. Soil Sci. 2007, 58, (3), 523-546.

51. Manceau, A.; Matynia, A., The nature of $\mathrm{Cu}$ bonding to natural organic matter. Geochim. Cosmochim. Acta 2010, 74, (9), 2556-2580.

52. European commission CO-FREE: Innovative strategies for copper-free low input and organic farming systems; 2016. https://cordis.europa.eu/project/id/289497 (17 December 2019).

53. ECHA, Characterisation of dose [concentration]-response for environment. In Guidance on Information Requirements and Chemical Safety Assessment, European Chemicals Agency: Helsinki, Finland, 2008.

54. Smolders, E.; Oorts, K.; Van Sprang, P.; Schoeters, I.; Janssen, C. R.; McGrath, S. P.; McLaughlin, M. J., Toxicity of trace metals in soil as affected by soil type and aging after contamination: Using calibrated bioavailability models to set ecological soil standards. Environ. Toxicol. Chem. 2009, 28, (8), 1633-1642. 
55.Panagos, P.; Ballabio, C.; Meusburger, K.; Spinoni, J.; Alewell, C.; Borrelli, P., Towards estimates of future rainfall erosivity in Europe based on REDES and WorldClim datasets. J. Hydrol. 2017, 548, 251-262.

56. Gottschalk, P.; Smith, J. U.; Wattenbach, M.; Bellarby, J.; Stehfest, E.; Arnell, N.; Osborn, T. J.; Jones, C.; Smith, P., How will organic carbon stocks in mineral soils evolve under future climate? Global projections using RothC for a range of

57. Tack, F. M. G.; Meers, E., Assisted phytoextractions helping plants to help us. Elements 2010, 6, 383-388.

58. Schmidt, U., Enhancing phytoextraction: The effect of chemical soil manipulation on mobility, plant accumulation, and leaching of heavy metals. J. Environ. Qual. 2003, 32, (6), 1939-1954.

59. Thomas, C. S.; Gubler, W. D.; Leavitt, G., Field testing of a powdery mildew disease forecast model on grapes in California. . Phytopathology 1994, 84, 1070.

61. Ongena, M.; Jacques, P., Bacillus lipopeptides: versatile weapons for plant

60.Pedneault, K.; Provost, C., Fungus resistant grape varieties as a suitable alternative for organic wine production: Benefits, limits, and challenges. Sci. Hortic. 2016, 208, 57-77. disease biocontrol. Trends Microbiol. 2008, 16, (3), 115-125. 
62. Harm, A.; Kassemeyer, H.-H.; Seibicke, T.; Regner, F., Evaluation of chemical and natural resistance inducers against Downy Mildew (Plasmopara viticola) in grapevine. Am. J. Enol. Viticult. 2011, 62, (2), 184-192.

63. Abdu-Allah, G. A. M.; Abo-Elyousr, K. A. M., Effect of certain plant extracts and fungicides against powdery mildew disease of grapevines in upper Egypt. Arch. Phytopathol. Plant Protect. 2017, 50, (19-20), 957-969.

64. Soustre-Gacougnolle, I.; Lollier, M.; Schmitt, C.; Perrin, M.; Buvens, E.; Lallemand, J. F.; Mermet, M.; Henaux, M.; Thibault-Carpentier, C.; Dembele, D.; Steyer, D.; Clayeux, C.; Moneyron, A.; Masson, J. E., Responses to climatic and pathogen threats differ in biodynamic and conventional vines. Sci. Rep. 2018, 8, 16857-16871.

65.Karimi, B.; Cahurel, J.-Y.; Gontier, L.; Charlier, L.; Chovelon, M.; Mahé, H.; Ranjard, L., A meta-analysis of the ecotoxicological impact of viticultural practices on soil biodiversity. Environ. Chem. Lett. 2020, 18, (6), 1947-1966.

601

602

\section{FOR TOC ONLY}




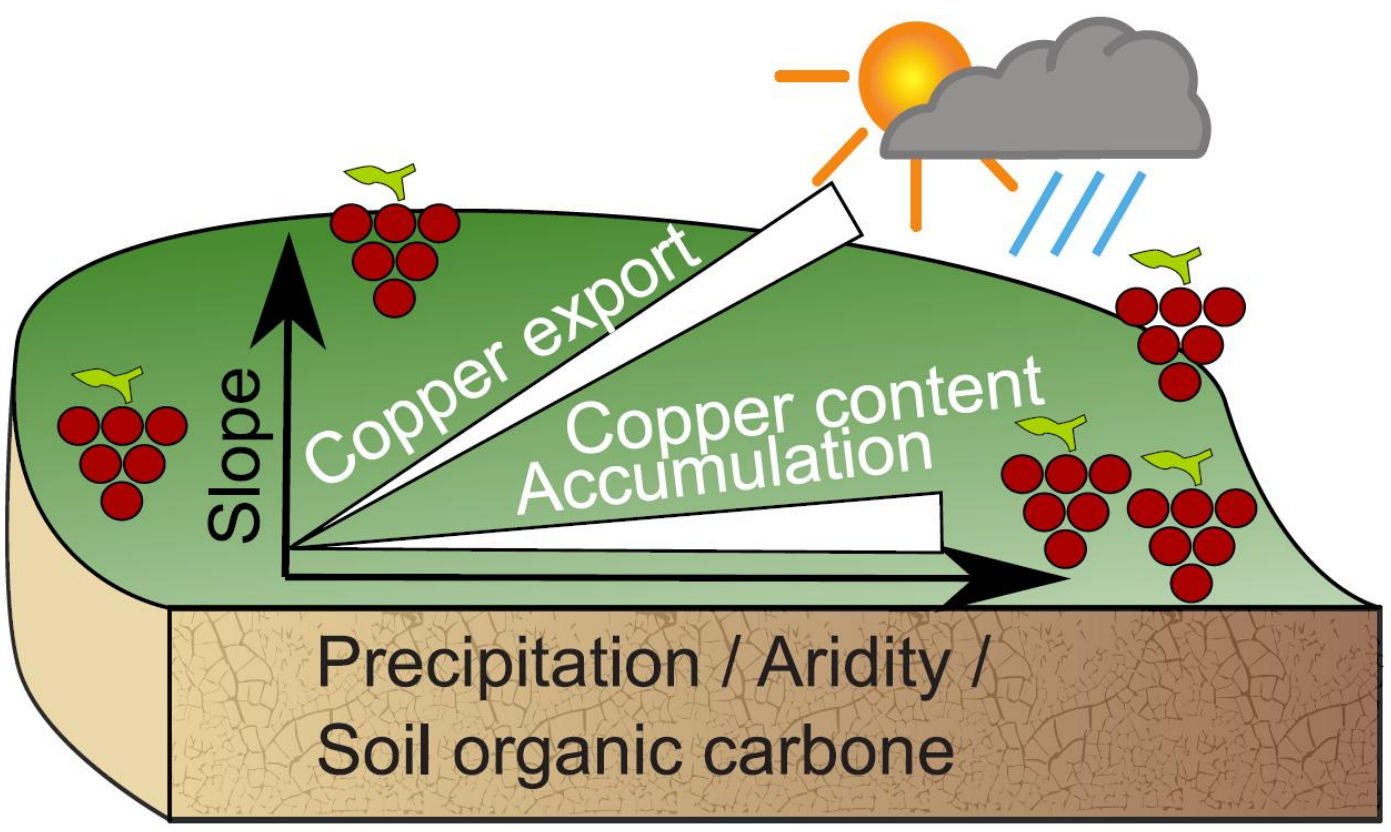

603 